\title{
Distribusi Southeast Asia Ovalocytosis (SAO) pada Berbagai Populasi Masyarakat di Kepulauan Sunda Kecil
}

\author{
Distribution of Southeast Asia Ovalocytosis (SAO) in Populations of Lesser Sunda \\ Islands
}

\section{Fransiska Lanni}

Fakultas Biologi Atma Jaya Yogyakarta, Jl. Babarsari 44, Yogyakarta, Indonesia 55281

E-mail :frlanni@mail.uajy.ac.id

\begin{abstract}
The presence of some genetic markers related to malaria as hemoglobinopathies, enzymophaties and ovalocytosis in populations of Lesser Sunda Islands are presumed to be quite high, since this archipelago is mostly malaria endemic. To elucidate the problem, a series of observations had been done among 579 blood samples which were collected from five different populations (Balinese, Sasak, Sumbawanese, Sumbanese, and Alorese) representing inhibitant of Lesser Sunda Islands. In this paper we present the distribution of Southeast Asia Ovalocytosis (SAO) which was detected by microscopic examination of the red blood cell morphology. Among these, 38 subjects were suspected as SAO whereas the incidence ranges from $2.2 \%$ in Balinese to $15.7 \%$ in Alorese. It was predicted that the high incidence of SAO in Alorese might be associated with malaria selection to compensate the absence of hemoglobinophaties in this population.
\end{abstract}

Key words: SAO, Lesser Sunda islands, malaria endemic

Diterima: 21 Agustus 2003, disetujui: 6 Januari 2004

\section{Pendahuluan}

Untuk mencapai umur 120 hari, eritrosit normal memerlukan bentuk khusus agar dapat bertahan dalam sistem sirkulasi intra maupun ekstravaskular (Luzatto and Gordon-Smith, 1999). Lempeng bikonkaf merupakan bentuk selektif yang fleksibel bagi eritrosit, sehingga leluasa melalui mikrosirkulasi sistem retikuloendotelial (SRE) tanpa mengalami cidera sehingga hemolisis prematur dapat dihindari. Bentuk bikonkaf eritrosit membutuhkan struktur membran dan sitoskeleton khusus agar permeabilitas membran dan transport ion dapat berlangsung normal (Schrier et al., 1985). Mutasi yang terjadi gen penyandi protein membran dapat menggangu permeabelitas membran sehingga terjadi hemolisis dini yang memperpendek umur eritrosit (Galagher et al., 1997).
Membran eritrosit tersusun atas lipid bilayer yang terdiri dari kira-kira $50 \%$ protein, $40 \%$ lipid, dan $10 \%$ lainnya karbohidrat (Schrier, 1985). Kelainan atau mutasi pada gen penyandi protein sitoskeleton dapat mengubah integritas membran yang menyebabkan perubahan bentuk eritrosit dari bikonkaf menjadi sferis, elips maupun oval. Bentuk eritrosit abnormal ini bersifat kaku dan mudah terjebak pada SRE dan terjadilah lisis ekstravaskular (Luzatto and Gordon-Smith, 1999). Kebanyakan abnormalitas membran eritrosit merupakan kelainan bawaan yang diwariskan secara autosomal dominan dengan manifestasi klinis ringan sampai sedang pada bentuk heterozigotnya, serta anemia hemolitik berat sampai letal pada bentuk homozigotnya (Hanspal et al., 1993) .

Berbagai jenis kelainan pada membran eritrosit telah ditemukan antara lain 
sferositosis, eliptositosis, piropoikilositosis (HPP), akantositosis, stomatositosis, dan ovalositosis Asia Tenggara (SAO) yang semuanya bersifat herediter (Delaunay, 1995). SAO merupakan bentuk kerusakan membran eritrosit paling sering dijumpai pada populasi di Asia Tenggara meliputi Thailand, Malaysia, Filipina (Joralim, 1991), termasuk Indonesia (Takeshima et al., 1994; Alimsardjono et al., 1997). Selain di Asia Tenggara, SAO juga dijumpai di Mauritius dan Madagaskar di sebelah barat dan Melanesia di sebelah Selatan (Mgone et al., 1996; O’Donnell et al., 1998). Penelitian tentang resistensi SAO terhadap malaria telah dibuktikan baik secara in vivo oleh Allen et al. (1996) maupun in vitro oleh Mgone et al. (1996), hasil keduanya menunjukkan bahwa Plasmodium memberikan seleksi positif terhadap SAO.

Sejauh ini, baru ditemukan satu mutasi tunggal penyebab SAO yaitu delesi $27 \mathrm{bp}$ pada kodon 400 - 408 atau nukleotida 1198 - 1224 exon 11 pada gen penyandi protein band-3 yang terletak pada lengan pendek kromosom 17 (17q21) (Sarabia et al., 1993). Protein tersebut merupakan glikoprotein integral membran eritrosit yang bertanggung jawab atas morfologi eritrosit (Tanner, 1988). Sebagai akibat delesi tersebut, sebanyak sembilan asam-amino pada perbatasan antara membran sitoplasmik dan domain transmembran protein band-3 hilang, sehingga bentuk eritrosit berubah dari bikonkaf menjadi oval. Perubahan bentuk tersebut mengakibatkan membran eritrosit menjadi kaku dan mekanisme transport terganggu (Serjeantson et al., 1977). Gangguan bentuk dan transport ion pada SAO diduga sebagai penyebab utama eritrosit tersebut resisten terhadap invasi plasmodium (Joralim et al., 1991). Penurunan transport ion pada individu heterozigot mencapai $40 \%$ dari normal, sehingga bentuk homozigotnya selalu bersifat lethal (Schoefield et al., 1994).

Mengingat sebagian besar daerah di kepulauan Sunda Kecil merupakan daerah endemik malaria, maka diduga keberadaan SAO cukup tinggi. Namun demikian belum pernah dilaporkan insidensi SAO pada berbagai populasi masyarakat di daerah tersebut, sehingga dalam penelitian ini telah dilakukan skrining SAO pada berbagai populasi di daerah tersebut.

\section{Metode Penelitian}

\section{Populasi dan Sampel}

Populasi yang diteliti meliputi suku Bali, Sasak, Sumbawa, Sumba dan Alor seperti tertera pada Tabel 1. Jumlah sampel darah yang berhasil dikoleksi dari lima populasi tersebut adalah 579 yang terdiri dari 277 orang laki-laki dan 302 orang perempuan. Sampel diambil dari darah vena orang sehat dewasa sebanyak $5 \mathrm{ml}$ dengan bantuan vacumtainer (Terumo) yang telah berisi antikoagulan heparin. Jumlah sampel untuk tiap populasi di atas 100 orang (kecuali Bali), tidak ada hubungan keluarga satu sama lain dan dianggap mewakili populasi tersebut sampai tiga generasi ke atas.

Tabel 1. Populasi, lokasi pengambilan sampel, rasio jenis kelamin dan jumlah sampel darah yang terkoleksi dari lima populasi masyarakat di kepulauan Sunda Kecil yang diteliti

\begin{tabular}{|c|c|c|c|c|c|}
\hline \multirow[t]{2}{*}{ No } & \multirow[t]{2}{*}{ Populasi } & \multirow{2}{*}{ Lokasi Pengambilan Sampel } & \multicolumn{3}{|c|}{ Jumlah Sampel } \\
\hline & & & $\mathbf{L}$ & I $\mathbf{P}$ & $\Sigma$ \\
\hline 1 & Bali & Denpasar (Bali) & 48 & 34 & 82 \\
\hline 2 & Sasak & Mataram (NTB) & 70 & 68 & 138 \\
\hline 3 & Sumbawa & Bima (NTB) & 43 & 75 & 118 \\
\hline 4 & Sumba & Waingapu (NTT) & 57 & 63 & 120 \\
\hline \multirow[t]{2}{*}{5} & Alor & Kalabahi (NTT) & 59 & 62 & 121 \\
\hline & & Total & 277 & 302 & 579 \\
\hline
\end{tabular}




\section{Skrining SAO}

Penapisan ovalositosis dilakukan dengan pemeriksaan mikroskopik morfologi eritrosit pada sediaan apus darah dengan pewarnaan Giemsa. Jika lebih dari 50\% per satuan luas pandang, sel darah merahnya berbentuk oval maka dinyatakan SAO (Amato and Brooth, 1977).

\section{Hasil dan Pembahasan}

Pada penelitian ini penapisan
ovalositosis hanya berdasarkan pada
pemeriksaan preparat apus darah dengan
kriteria SAO lebih dari $50 \%$ per satuan luas
pandang (Gambar 1). Kriteria tersebut telah
berhasil menjaring 38 sampel darah yang
dicurigai sebagai SAO (Tabel 2).

Tabel 2. Distribusi ovalositosis pada berbagai populasi Indonesia berdasarkan pemeriksaan morfologi eritrosit.

\begin{tabular}{lcccc}
\hline \hline \multirow{2}{*}{ Populasi } & Jumlah sampel & \multicolumn{2}{c}{ Dicurigai sbg ovalositosis* } \\
& & Laki---aki & : Perempuan : & Jumlah (\%) \\
\hline \hline 1. Bali & 82 & 1 & 1 & $2(2,4)$ \\
2. Sasak & 138 & 1 & 2 & $3(2,2)$ \\
3. Sumbawa & 118 & 3 & 2 & $5(4,2)$ \\
4. Sumba & 120 & 4 & 5 & $9(7,5)$ \\
5. Alor & 121 & 7 & 12 & $19(15,7)$ \\
\hline \hline \multicolumn{1}{c}{ Total } & 579 & 16 & 22 & 38 \\
\hline \hline
\end{tabular}

* angka dalam kurung dalam persen.

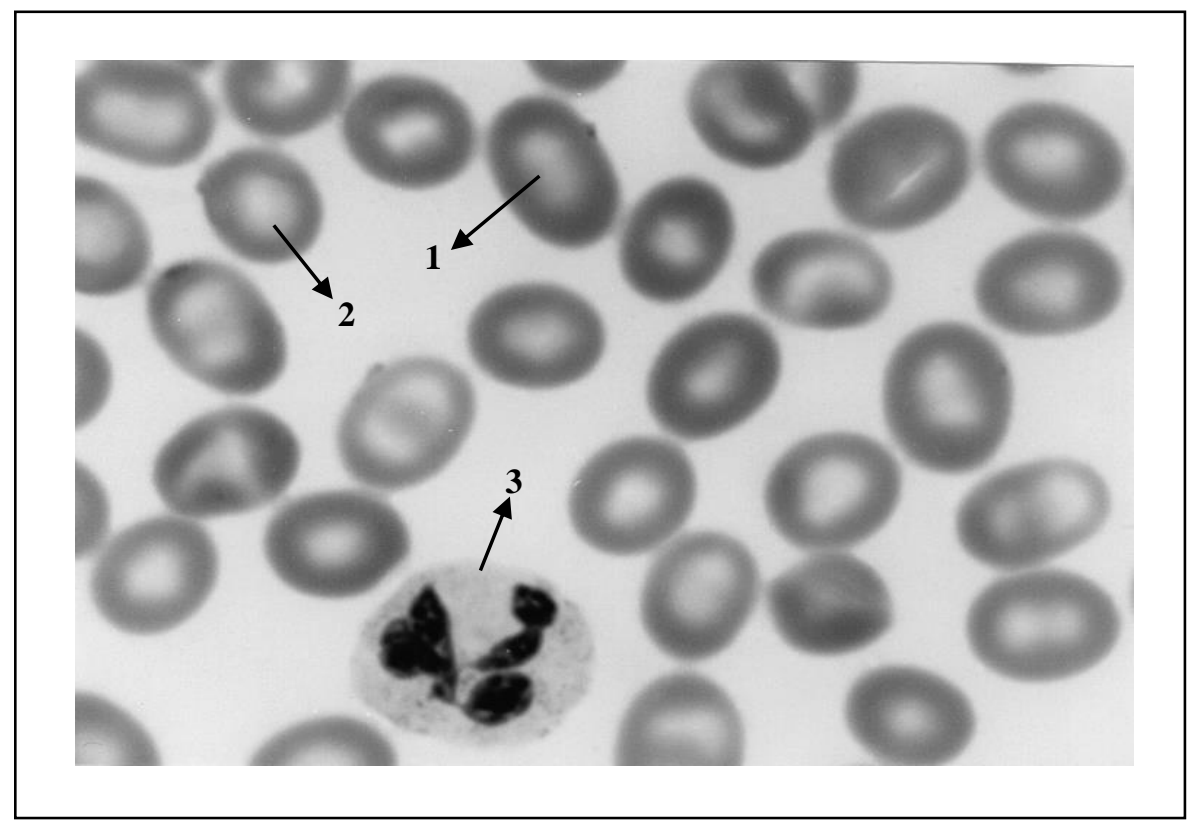

Gambar 1. Gambaran mikroskopik ovalositosis dengan pembesaran $1000 \mathrm{x}$. Lebih dari $50 \%$ dari total eritrosit dalam satu satuan luas pandang berbentuk oval. $1=$ eritrosit $\mathrm{SAO}, 2=$ eritrosit normal dan $3=$ leukosit. 
Mengingat waktu dan biaya yang terbatas, maka penapisan SAO dalam penelitian ini hanya dilakukan berdasarkan pemeriksaan morfologi eritrosit saja, walaupun telah diketahui bahwa penapisan dengan pemeriksaan molekular (DNA) jauh lebih sensitif. Dengan menggunakan teknik PCR misalnya, Yusuf et al. (1999) telah menemukan beberapa kasus ovalositosis (SAO) tanpa menunjukkan perubahan bentuk pada eritrositnya. Oleh karena itu maka ada kemungkinan bahwa jika penapisan SAO pada penelitian ini dilakukan dengan perpaduan kedua teknik tersebut, maka jumlah SAO yang terjaring mungkin akan lebih besar.

Dari beberapa penelitian terdahulu telah dilaporkan bahwa daerah sebaran SAO meliputi beberapa daerah di Asia Tenggara seperti Thailand, Malaysia, dan Filipina (Joralim, 1991) sampai Madagaskar, Mauritius, Melanesia, dan Papua (Mgone et al., 1996; O'Donnell et al., 1998). Gambaran distribusi SAO pada penelitian ini terkesan unik, karena dijumpai pada semua populasi di Sunda Kecil yang meliputi Bali, Sasak, Sumbawa, Sumba, dan Alor dengan frekuensi 2,2\% - 15,7\% (Tabel 2). Frekuensi SAO yang tinggi pada populasi Sunda Kecil mungkin dapat dihubungkan dengan keberadaan alel mutan tersebut yang cukup tinggi pada populasi di kawasan timur Indonesia. Pada populasi Papua misalnya pengemban genetik ini mencapai 27\% (Yusuf et al., 1999). SAO juga dilaporkan dijumpai cukup tinggi pada populasi Melanesia bagian selatan (Mgone et al., 1996).

Mengingat Alor merupakan daerah hiperendemik malaria, barangkali tingginya prevalensi kelainan membran eritrosit tersebut merupakan hasil mekanisme seleksi alam terhadap malaria dan sebagai kompensasi terhadap ketidakberadaan hemoglobinopati (Lanni, 2002). Jika dikaitkan dengan populasi Papua yang juga memiliki prevalensi yang tinggi terhadap pengemban genetik tersebut, tampaknya kedua populasi memang mempunyai banyak kesamaan. Bukti linguistik menunjukkan bahwa bahasa yang digunakan oleh kedua populasi di atas berasal dari rumpun bahasa yang sama yaitu Papua atau nonAustronesia (Bellwood, 1995). Masih menjadi pertanyaan apakah elemen Australomelanesoid pada populasi Alor tersebut merupakan peninggalan sisa-sisa Australomelanesoid pada awal penghunian Indonesia. Karena ada dugaan bahwa bahasa Papua yang digunakan suku Alor sekarang ini datangnya langsung dari Irian sebagai migrasi balik Australomelanesoid yang terjadi kemudian. Dugaan tersebut diperkuat dengan ditemukannya beberapa artifak pendukung teknologi pertanian yang sama pada kedua populasi tersebut (Bellwood, 1989).

\section{Kesimpulan}

Dari hasil penelitian ini dapat disimpulkan bahwa SAO dijumpai cukup pada suku Bali, Sasak, Sumbawa, Sumba dan Alor. Frekuensi tertinggi dijumpai pada suku Alor sebesar $15,7 \%$.

\section{Ucapan terima kasih}

Penulis mengucapkan banyak terima kasih kepada Prof. dr. Sangkot Marzuki MSc, PhD, DSc, Prof. Dr. dr. HM Ismadi dan Prof. dr. Abdul Salam M. Sofro, $\mathrm{PhD}$ yang telah banyak memberi bimbingan selama penelitian berlangsung.

\section{Daftar Pustaka}

Alimsardjono H., Mukono I.S., Dachlan Y.P. and Matsuo M., 1997. Deletion of 27 nucleotides within exon 11 of the band-3 gene identified in ovalocytosis in Lombok Island, Indonesia. Jpn. J. Hum. Genet. 42 : 233 - 236.

Allen S.J., O’Donnell A., Alexander N.D.E., Mgone C.S., Peto T.E.A., Clegg J.B., Alkper M.P. and Weatherall D.J., 1996. Prevention of cerebral malaria in children in Papua New Guinea by Southeast Asian Ovalocytosis band-3. Am. J. Trop. Med. Hyg. 60 (6) : 1056 -1060 .

Amato D. and Brooth P.B.,1977. Hereditary ovalocytosis in Melanesians. Papua New Guinea Med. J. 20 : 26 - 32. 
Bellwood P.S., 1989. The colonization of the Pacific: some current hypotheses. In Hill A.V.S. and Serjeantson S.W. (eds); The colonization of the Pacific; a Genetic Trial. Clarendon Press. Oxford. UK.

Bellwood P., 1995. Austronesian prehistory in Southeast Asia: homeland, expansion and transformation. In Bellwood P., Fox J.J. and Tryon D. (Eds) The Austronesians: Comparative and Historical Perspective. Department of Anthropology. Research School of Pacific and Asian Studies. Australian National University. Canberra., Australia.

Delaunay J. (1995) Genetic disorders of red cell membranes. FEBS Letters, 369: 34-37.

Gallagher P.G. and Ferriera J.D.S., 1997. Molecular basis of erythrocyte membrane disorders. Curr. Opin. in Haematol. 4 : 128-135.

Hanspal M., Hanspal J.S., Sahr K.E., Fibach E., Nachman J. and Palek J. 1993. Molecular basis of spektrin deficiency in hereditary pyropoikilocytosis. Blood. 82 (5):1652-1660.

Jarolim P., Palek J., Amato D., Hassan K., Sapak B., Nurse G.T., Rubin H.L., Zhai S., Sahr K.E. and Liu S.C., 1991. Deletion in erythrocyte band-3 gene in malaria resistant Southeast Asian Ovalocytosis. Proc. Natl. Acad. Sci. USA. 88 : 11022-11026.

Lanni F. 2002. Heterogenitas Molekular Gena Globin- $\beta$ di Indonesia : Kaitannya dengan Pola Penyebaran Thalassemia- $\beta$ serta Hubungan Genetik antar Populasi di Indonesia. Disertasi S-3, Fakultas Kedokteran UGM, Yogyakarta.

Luzzatto L. and Gordon-Smith E.C. 1999. Inherited haemolytic anaemias in Hoffbrand A.V., Lewis S.M. and Tuddenham E.G.D. (eds); Postgraduate Haematology $4^{\text {th }}$ edn. Butterwoth-Heinemann Int. Publ. Oxford.

Mgone C.S., Koki G., Paniu M.M., Kono J., Bhatia K.K., Genton B., Alexander N.D.E. and Alpers M.P. (1996) Occurrence of the erythrocyte band-3 (AE-1) gene deletion in relation to malaria endemicity in Papua New Guinea. Trans. Res. Soc. Trop. Med. Hyg. 90 : 228-231.
O’Donnel A., Allen S.J., Mgone C.S., Martinson J.J., Clegg J.B. and Weatherall D.J., 1998. Red cell morphology and malaria anaemia in children with Southeast-Asian Ovalocytosis band-3 in Papua New Guinea. Br. J. Haematol .101 : 407-412.

Sarabia V.E., Casey J.R. and Reithmeier R.A.F., 1993. Molecular characterization of the band-3 protein from Southeast Asian Ovalocytosis. J. Biol. Chem. 268 (14): 10676-10680.

Schofield A.E., Martin P.G., Pillett D. and Tanner M.J. 1994. The structure of the human red blood cell anion exchanger (EPB3, AE1, band-3) gene. Blood. 84(6): 2000-2012.

Schrier S.L. (1985). Red cell membrane biologyintroduction. Clin. Haematol. 14.1-12.

Serjeantson S., Bruson K., Amato D. and Babona D., 1977. Malaria and hereditary ovalocytosis. Hum. Genet. 37 : 161-167.

Takeshima Y., Sofro A.S.M., Suryantoro P., Narita N. and Matsuo M., 1994. Twenty seven nucleotides deletion within exon 11 of the erythrocyte band-3 gene in Indonesia ovalocytosis. Jpn. J. Hum. Genet. 39 : 181185.

Tanner M.J., Martin P.G. and High S. 1988. The complete amino acid sequence of the human erytrocyte membran anion-transport protein deduced from the cDNA sequence. Biochem J. 256: 703-708.

Yusuf I., Pramoonjago P., Satyagraha A., Setiadi Y., Lanni F. and Marzuki S., 1999. On the origin and spread of the erythrocyte bnad-3 protein which underlies the Southeast asia Ovalocytosis. Abstracts $2^{\text {nd }} \mathrm{HUGO}$ Pacific Meeting. Denpasar. 